\title{
Differential gene expression profiles of radioresistant oesophageal cancer cell lines established by continuous fractionated irradiation
}

\author{
K Fukuda*,', C Sakakura', K Miyagawa', Y Kuriu', S Kin', Y Nakase', A Hagiwara', S Mitsufuji' ${ }^{2}$, Okazaki $^{3}$, \\ Y Hayashizaki ${ }^{3}$ and $\mathbf{H}$ Yamagishi'
}

'Division of Digestive Surgery, Kyoto Prefectural University of Medicine, Kawaramachi-hirokoji, Kamigyo-ku, Kyoto 602-8566, Japan; ${ }^{2}$ Division

of Gastroenterology and Hepatology, Kyoto Prefectural University of Medicine, Kawaramachi-hirokoji, Kamigyo-ku, Kyoto 602-8566, Japan;

${ }^{3}$ Genomic Sciences Center, RIKEN, Yokohama Institute, 1-7-22 Suehiro-cho, Tsurumi-district. Yokohama 230-0045, Japan

\begin{abstract}
Radiation therapy is a powerful tool for the treatment of oesophageal cancer. We established radioresistant cell lines by applying fractionated irradiation in order to identify differentially expressed genes between parent and radioresistant cells. Six oesophageal cancer cell lines (TE-2, TE-5, TE-9, TE- I3, KYSE I 70, and KYSE I 80) were treated with continuous 2 Gy fractionated irradiation (total dose 60 Gy). We compared expression profiles of each parent and radioresistant lines on a cDNA microarray consisting of 2II 68 genes. In the fractionated irradiation trial, four radioresistant sublines (TE-2R, TE-9R, TE-I3R, KYSE I70R) were established successfully, and we identified 19 upregulated and 28 downregulated genes common to radioresistant sublines. Upregulated genes were associated with apotosis and inflammatory response (BIRC2 and COX-2), DNA metabolism (CD73), and cell growth (PLAU). Downregulated genes were associated with apoptosis (CASP6), cell adhesion (CDHI and CDH3), transcription (MLL3), and cell cycle (CDK6). Some of these genes were known to be associated with radiation response, such as COX-2, but others were novel. Reverse transcription-polymerase chain reaction confirmed that genes selected by CDNA microarray were overexpressed in clinical specimens of radioresistant cases. Global gene analysis of radioresistant sublines may provide new insight into mechanisms of radioresistance and effective radiation therapy.

British Journal of Cancer (2004) 9I, I543- 1550. doi: I0.1038/sj.bjc.6602187 www.bjcancer.com

Published online 14 September 2004

(c) 2004 Cancer Research UK
\end{abstract}

Keywords: radioresistance; oesophageal cancer; cDNA microarray; fractionated irradiation

Radiation therapy for oesophageal cancer is effective in selected patients but there are patients who show no response and suffer from side effects such as immunosuppression. Many factors determine tumour resistance in clinical radiotherapy, including tumour size, hypoxia, and intrinsic radiosensitivity. Clinical data suggest that size is one of the most important factors to predict outcome for cancer patients after radiotherapy (Eifel et al, 1994). The most obvious explanation for this is related to the number of clonogenic cells that must be sterilised. However, because of heterogeneity in both patient and tumour characteristics, the volume effect is less pronounced than would be expected from a simple proportionality between the number of clonogenes and volume.

Chronic exposure of cells to an ionising radiation induces an adaptive response that results in increased tolerance to the subsequent cytotoxicity caused by this ionising radiation (Russell et al, 1995; Dahlberg et al, 1999; Pearce et al, 2001). Although the factor that ultimately determines a cell's radiosensitivity is quite complex, several researchers have pointed out that the induction of apoptosis is correlated with the biological effectiveness of the radiation (Dewey et al, 1995; Meyn et al, 1996). To investigate

*Correspondence: Dr K Fukuda; E-mail: ken-f@mvg.biglobe.ne.jp Received 20 May 2004; revised 21 July 2004; accepted 17 August 2004; published online 14 September 2004 clinical radioresistance, regimens of fractionated ionising radiation (FIR) in vitro have been used to determine molecular mechanisms underlying radioresistance. Tumour cells are heterogeneous with respect to cure-limiting characteristics, and the radioresistant phenotype is correlated often with several factors, including alterations in cell cycle checkpoints, slowed growth, and decreased apoptosis (Coleman and Stevenson, 1996; Maity et al, 1997). Recently, a relationship between radioresistance and expression of several genes has been reported, including p53 (Brachman et al, 1993; Biard et al, 1994), ras (Sklar, 1988), raf-1 (Kasid et al, 1987), and bcl-2 (Kitada et al, 1996). Biard et al (1994) reported the first model in which cells bearing a p53 gene mutation display enhanced sensitivity to ionising radiation, although Brachman et al (1993) reported that the p53 gene mutation does not correlate with the radiosensitivity of 24 head and neck cancer cell lines. The activation of raf has been positively correlated with the radioresistance of head and neck squamous cell carcinomas (Riva et al, 1995), and certain cell cycle- and apoptosis-related genes have also been correlated with radiosensitivity; for example, loss or dysfunction of p16 renders resistance to melanoma cells against the ionising radiation, whereas the expression of exogenous wildtype p16 and p 21 in glioblastoma cells can induce radiosensitivity (Hsiao et al, 1997; Matsumura et al, 1997). Overexpression of bcl-2 in multiple tumour cells increases radiation resistance (Gasparini et al, 1995; Weller et al, 1995; Mackey et al, 1998), and bax, the other number of the bcl-2 family, antagonises the bcl-2 function by 
forming a heterodimer. Although such discoveries have helped develop a partial understanding of the molecular mechanisms responsible for cellular radiosensitivity, the entire process still remains to be elucidated. The advent of microarray gene expression technology permits the simultaneous analysis of the expression levels of thousands of genes (DeRisi et al, 1996; Eisen et al, 1998; Golub et al, 1999). Therefore, a study on these molecular genetic events, which are related to radiosensitivity, can be conducted (Hanna et al, 2001; Kitahara et al, 2002). This may also lead to identifying and gene regulatory pathways resulting in the development of cell resistance to therapeutic procedure. However, little is known about the clinical significance of these genes in order to estimate radiotherapy effectiveness.

We have tried to identify differentially expressed genes between radiosensitive and radioresistant oesophageal cancer cell lines. Radioresistant sublines were established by FIR, and we applied cDNA microarrays to the parent and radioresistant sublines. Finally, for the clinical application of selected genes, we studied the expression status of COX-2 and BIRC2 mRNA in biopsy specimens obtained from 'radio-effective' and 'noneffective' cases of oesophageal cancer.

\section{MATERIALS AND METHODS}

\section{Cells and cell culture}

The human oesophageal squamous cancer cell lines TE-2, TE-5, TE-9, and TE-13 were obtained from the Cell Resource Center for Biomedical Research Institute of Development, Aging and Cancer (Tohoku University, Sendai, Japan) (Nishihira et al, 1993). Cell lines KYSE170 and KYSE180 were kindly provided by Dr Shimada (Kyoto University, Kyoto, Japan) (Shimada et al, 1992). Cells were cultured in RPMI-1640 (Life Technologies, Grand Island, NY, USA) with $100 \mathrm{U} \mathrm{ml}^{-1}$ of penicillin. $100 \mu \mathrm{g} \mathrm{ml}^{-1}$ of streptomycin, and $10 \%$ fetal bovine serum, and incubated at $37^{\circ} \mathrm{C}$ in $5 \% \mathrm{CO}_{2} / 95 \%$ air.

\section{Establishment of radioresistant cell lines}

The cells were first grown to approximately $50 \%$ confluence in vented $25-\mathrm{cm}^{2}$ culture flasks. Cells were treated with $2 \mathrm{~Gy}$ of X-ray irradiation $(120 \mathrm{kV}$ and $3.5 \mathrm{~mA}$ for $4 \mathrm{~min}$ with a $0.5-\mathrm{mm}$ Al filter) using an X-ray generator (M-150 WE: SOFTEX Co., Tokyo, Japan) and then returned to the incubator. When they reached approximately $90 \%$ confluence, the cells were trypsinised and subcultured into new flasks. When they reached approximately $50 \%$ confluence, the cells were again irradiated (second fraction). The fractionated irradiations were continued until the total doses reached $60 \mathrm{~Gy}$. The parental cells were subjected to identical trypsinisation, replating, and culture conditions but were not irradiated. For all assays on irradiated cells, there was at least a 2-week interval between the last 2 Gy FIR and the experiment.

\section{Assay for radiosensitivity}

Cell survival after X-irradiation was measured by clonogenic assay. The cells $\left(10^{5}\right.$ cells per dish) were incubated at $37^{\circ} \mathrm{C}$ for $48 \mathrm{~h}$ in the growth medium and were irradiated at different doses ranging from 0 to $10 \mathrm{~Gy}$. The cells were harvested with EDTA-trypsin immediately after irradiation. Subsequently, a constant number of cells were plated in each $60-\mathrm{mm}$ tissue culture dish (Iwaki Glass, Chiba, Japan), and incubated at $37^{\circ} \mathrm{C}$ for $10-14$ days (three plates in each radiation dose). After fixation with formalin and staining with $0.1 \%$ crystal violet, colonies consisting of 50 cells or more were counted under a light microscope, and the surviving fraction was determined.

All survival curves represent at least three independent experiments. The data were fitted to the single hit, multitarget formula, where survival $(S)$ is related to dose $(D)$ by the expression
$S=1-\left(1-\mathrm{e}^{-D D_{0}}\right)^{n} \fallingdotseq n \mathrm{e}^{-D D_{0}}$. $D_{0}$ was used as a parameter to indicate the amount of irradiation required to reduce the survival fraction to approximately 0.37 from the survival curve.

\section{Flow cytometry}

Cells were analysed during exponential growth. They were trypsinised, rinsed in PBS, and fixed in 70\% ethanol. Before analysis, cells were spun out of ethanol and resuspended in $1.6 \mathrm{ml}$ PBS, $0.2 \mathrm{ml}$ propidium iodide (PI) $400 \mu \mathrm{g} \mathrm{ml}^{-1}$ (Sigma Chemical Co., Poole, UK), and $0.2 \mathrm{ml}$ RNase $1 \mathrm{mg} \mathrm{ml}^{-1}$ (Sigma). After incubation for $30 \mathrm{~min}$ at $37^{\circ} \mathrm{C}$, the cells were spun down and resuspended in PBS. The cells were analysed by a FACScan flow cytometer (Becton Dickinson, San Jose, CA, USA) for DNA content using PI and a photomultiplier masked with a $610 \mathrm{~nm}$ long-pass filter. The data were analysed with a software program (Cell Quest; Becton Dickinson) with dead cells gated out using pulse processing. Two independent experiments were performed for each data set.

\section{RNA extraction}

Total RNA was extracted from each cell line with the RNeasy Midi Kit (QIAGEN) according to the manufacturer's protocol. The extracted RNA was treated with RNase-Free DNase set (QIAGEN) to remove any contamination of genomic DNA according to the manufacture's protocol.

\section{Microarray design, production, and hybridisation}

A $20 \mu \mathrm{g}$ portion of total RNA extracted from each radioresistant subline was labelled with $\mathrm{Cy} 3$, and RNA from each parent cell line was labelled with $\mathrm{Cy} 5$ as described elsewhere (Sakakura et al, 2002). We used the RIKEN human cDNA microarray, which contains 21168 genes. Hybridisation, washing, and scanning were carried out according to a published method (Sakakura et al, 2002). These slides were scanned on a ScanArray 5000 confocal laser scanner, and the images were analysed using IMAGENE (Bio Discovery, Los Angeles, CA, USA).

\section{Analysis of the data}

To improve the accuracy of the data, we did the experiment twice, labelling the same RNA template in two separate reactions. Data were normalised to the reference standard by subtracting (in log space) the median observed value if other than zero. We used only data points that were reproducible. To this end, we developed a filtering program, PRIM (Kaota et al, 2001). After filtering was finished, we compared the results of the two experiments by calculating a Pearson's correlation coefficient. If the coefficient was equal to or greater than 0.7 , we used the data in subsequent analysis. Ratio values from duplicate experiments were averaged, log-transformed (base 2), and stored in a table. Two-fold differences in up- or downregulated expression were used to identify altered genes. Hierarchical clustering and dendrogram figures were generated using Cluster and Tree-View software (http://rana.standford.edu).

\section{Quantitative RT - PCR}

A quantitative RT - PCR assay was used to follow-up on microarray data. A $4 \mu \mathrm{g}$ portion of total RNA was used for creation of singlestranded cDNA using the SuperScript Preamplification System for First Strand cDNA Synthesis (Life Technologies Inc., Rockville, MD, USA). The cDNA was diluted and quantitatively equalised for PCR amplification. The TaqMan PCR method using a Gene Amp 5700 Sequence Detection System (Applied Biosystems, Foster City, CA, USA) was performed according to the manufacturer's instructions. We used the primers and probes provided as 
Assay-on-Demand Gene Expression Products (Applied Biosystems). We used beta-actin as an internal control gene to normalise the expression rate of each gene. The details have been described elsewhere (Sakakura et al, 2004). Each experiment was carried out three times and the average was calculated.

\section{Clinical specimens}

Eight patients with advanced squamous cell carcinoma of the oesophagus ( $\mathrm{T} 3$ or $\mathrm{T} 4$ ) treated with preoperative radiation

Table I Clonogenic survival parameters fitting the data to a multitarget model

\begin{tabular}{|c|c|c|c|c|}
\hline Cell line & $D_{0}$ & $\begin{array}{l}\text { [95\% confidence } \\
\text { intervals }]\end{array}$ & $n$ & $\begin{array}{l}\text { [95\% confidence } \\
\text { intervals] }\end{array}$ \\
\hline \multicolumn{5}{|l|}{ TE-2 } \\
\hline Control & 0.75 & {$[0.68-0.84]$} & 2.63 & {$[1.49-4.63]$} \\
\hline \multirow{2}{*}{\multicolumn{5}{|c|}{ TE-5 }} \\
\hline & & & & \\
\hline Control & 0.69 & {$[0.57-0.85]$} & 13.97 & {$[4.05-48.24]$} \\
\hline Resistant & 0.73 & {$[0.65-0.85]$} & 9.25 & {$[4.21-20.29]$} \\
\hline \multicolumn{5}{|l|}{ TE-9 } \\
\hline Control & 1.14 & {$[1.00-1.32]$} & 1.76 & {$[1.21-2.55]$} \\
\hline Resistant & 1.71 & {$[1.53-1.93]$} & 1.60 & {$[1.15-2.23]$} \\
\hline \multicolumn{5}{|l|}{ TE- 13} \\
\hline Control & 1.49 & {$[1.39-1.61]$} & 2.42 & {$[1.76-3.34]$} \\
\hline Resistant & 1.83 & {$[1.70-1.98]$} & 2.61 & {$[1.97-3.45]$} \\
\hline \multicolumn{5}{|l|}{ KYSEI70 } \\
\hline Control & 1.31 & {$[1.17-1.49]$} & 2.46 & {$[1.55-3.90]$} \\
\hline Resistant & 1.76 & {$[1.49-2.17]$} & 2.73 & {$[1.38-5.37]$} \\
\hline \multicolumn{5}{|l|}{ KYSEI 80} \\
\hline Control & 0.91 & {$[0.84-0.99]$} & 2.43 & {$[1.74-3.38]$} \\
\hline Resistant & 0.97 & {$[0.89-1.07]$} & 2.02 & {$[1.43-2.84]$} \\
\hline
\end{tabular}

$D_{0}$ was used as a parameter to indicate the amount of irradiation required to reduce the survival fraction to approximately 0.37 from the survival curve. therapy at Kyoto Prefectural University of Medicine were subjected to preliminary clinical analysis. Tissue samples were obtained from the tumour site for an initial diagnostic biopsy, and $10-40 \mu \mathrm{g}$ of total RNA was extracted, and cDNA was synthesised from $4 \mu \mathrm{g}$ of total RNA as described. Preoperative irradiation was performed with a dose of $2 \mathrm{~Gy}$ per fraction to a total dose of $40 \mathrm{~Gy}$. The effects of radiation therapy in the resected specimens were determined using the histopathologic criteria of the Japanese Society for Esophageal Disease. Grade 0 represents no radiotherapy effect; grade 1, slightly effective, with viable cells recognised as more than one-third cancer cells; grade 2, moderately effective, with less than one-third cancer cells; and grade 3, markedly effective, with no viable cancer cells. We compared the expression rates of the selected genes for group A (patients whose histological grade after radiotherapy was either 0 or 1) with those for group B (patients whose histological grade after radiotherapy was either 2 or 3). A statistical analysis was performed using the Mann-Whitney $U$-test. The results with $P$ values of less than 0.05 were considered to be statistically

Table 2 Cell cycle distributions of the cell lines

\begin{tabular}{llll}
\hline Cell line & GI & S & G2/M \\
\hline $\begin{array}{llll}\text { TE-2 } \\
\text { Control }\end{array}$ & 54.9 & 18.1 & 27 \\
$\quad$ Resistant & 49 & 22.5 & 28.5 \\
$\begin{array}{l}\text { TE-9 } \\
\quad \text { Control }\end{array}$ & 57.3 & 16.1 & 26.6 \\
$\quad$ Resistant & 60.8 & 17.2 & 21.9 \\
TE-I3 & & 23.9 & 26.6 \\
$\quad$ Control & 49.5 & 24.7 & 22.2 \\
Resistant & 53.1 & 17 & 31.2 \\
KYSE-170 & 51.8 & 16.7 & 27.3 \\
$\quad$ Control & 56 & & \\
Resistant & &
\end{tabular}

Table 3 Upregulated genes in radioresistant sublines in comparison to parent cell lines

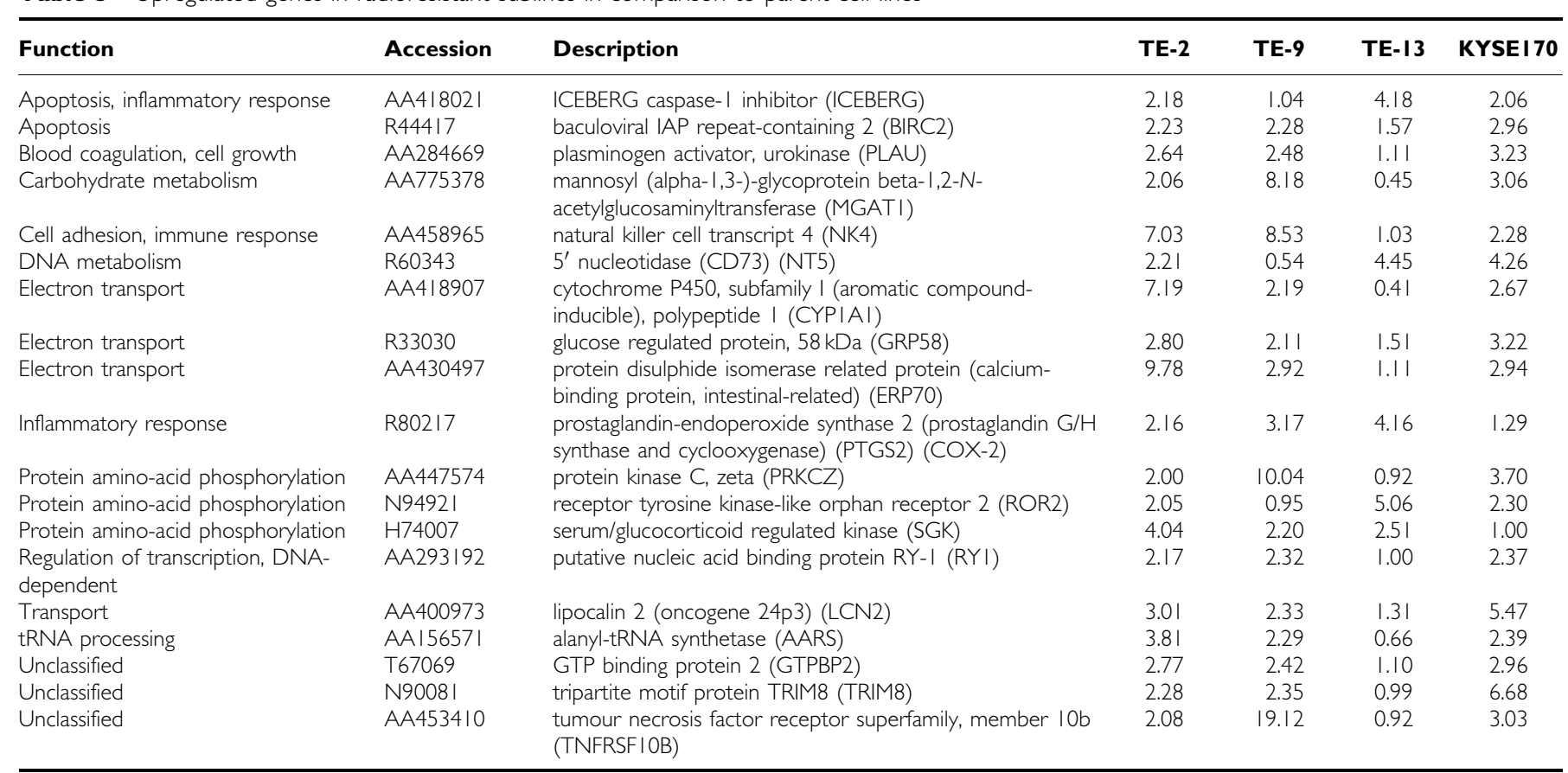

Representative functions of the genes as previously reported, accession number, gene name, and fold change of each radioresistant subline compared to their parent cell line are shown. Only the genes that showed more than two-fold change in at least three of the four radioresistant sublines are sorted by cDNA microarray data. 
significant. All experiments with clinical samples were conducted under institutional guidelines from the Ministry of Health and Welfare.

\section{RESULTS}

\section{Establishment of cell lines resistant to irradiation}

The human oesophageal cancer cell lines were treated with FIR, and all cell lines survived. The cell populations surviving FIR were analysed for their radiosensitivity using a clonogenic assay to assess survival after a single dose of radiation. The survival curve parameters for all cell lines are shown in Table 1 . There was a significant increase in radioresistance in the TE-2R, TE-9R, TE-13R, and KYSE-170R sublines compared to parental cell lines. Therefore, we considered these four sublines (TE-2R, TE-9R, TE-13R, and KYSE-170R) as radioresistant. All radioresistant sublines maintained a radioresistant phenotype for at lease 3 months after the cessation of FIR (data not shown).

\section{Cell cycle analysis}

Cells in $S$ phase tend to be more radiosensitive than cells in G1, and cells in G2-M are the most sensitive of all (Sinclair and Morton, 1966). Therefore, we examined the cell cycle distribution of cell lines using flow cytometry. The results in Table 2 show that, when in exponential growth, the lines have very similar cell cycle distributions and thus cannot be the explanation for the altered radiosensitivity of resistant cells. Other experiments also showed similar results (data not shown).

\section{Gene selection from cDNA microarray data analysis}

We performed global expression analysis of 21168 genes using a high-density cDNA microarray and compared the four profiles of parent lines and radioresistant sublines. We identified 47 genes as differentially expressed in at least three of the four radioresistant sublines. In all, 19 genes were upregulated (Table 3 ), and 28 were downregulated (Table 4). Upregulated genes were associated with apoptosis and inflammatory response (ICEBERG, BIRC2, and COX-2), DNA metabolism (CD73), and cell growth (PLAU). Other areas of upregulation included electron transport (CYP1A1, GRP58, and ERP70) and protein amino-acid phosphorylation (PRKCZ, ROR2, and SGK). Downregulated genes were associated with apoptosis (CASP6), cell adhesion (CDH1, CDH3, and PCDH9), and transcription (MLL3 and PRKCBP1), as well as cell cycle (CDK6 and CCNA2).

To verify the expression of genes identified in microarray experiments, real-time quantitative RT - PCR was performed using the same RNA as that used in the microarray analysis. We found that the results were in good agreement with those from the microarray data. Typical data for COX-2 and BIRC2 are shown in Figure 1.

\section{Effects of radiotherapy and expression of selected genes in clinical specimens}

In eight cases of squamous cell carcinoma of the oesophagus, COX-2 and BIRC2 mRNA expressions of pretreatment biopsy samples were assayed by quantitative RT-PCR. Although the

Table 4 Downregulated genes in radioresistant sublines in comparison to parent cell lines

\begin{tabular}{|c|c|c|c|c|c|c|}
\hline Function & Accession & Description & TE-2 & TE-9 & TE-I 3 & KYSEI 70 \\
\hline Apoptosis & W45688 & caspase 6, apoptosis-related cysteine protease (CASP6) & 0.09 & 0.14 & 0.04 & 0.04 \\
\hline Carbohydrate metabolism & AA193116 & glycerol-3-phosphate dehydrogenase I (soluble) (GPDI) & 1.64 & 0.37 & 0.44 & 0.37 \\
\hline Cell adhesion & H97778 & cadherin I, type I, E-cadherin (epithelial) $(\mathrm{CDHI})$ & 0.05 & 0.25 & 0.07 & 0.02 \\
\hline Cell adhesion & AA425217 & cadherin 3, type I, P-cadherin (placental) (CDH3) & 0.05 & 0.22 & 0.03 & 0.02 \\
\hline Cell adhesion & N63057 & protocadherin $9(\mathrm{PCDH} 9)$ & 0.43 & 0.07 & 0.69 & 0.36 \\
\hline Cell growth, cell-cell signalling & W5677। & $\begin{array}{l}\text { endometrial bleeding associated factor (left-right } \\
\text { determination, factor } \mathrm{A} \text {; transforming growth factor beta } \\
\text { superfamily) (EBAF) }\end{array}$ & 0.45 & 1.00 & 0.19 & 0.40 \\
\hline Epidermal differentiation & W23757 & keratin 13 (KRTI3) & 0.37 & 0.30 & 3.32 & 0.19 \\
\hline Intracellular protein transport & R28020 & RAB2, member RAS oncogene family (RAB2) & 0.07 & 0.20 & 0.03 & 0.03 \\
\hline Intracellular signalling cascade & R91570 & signal transducer and activator of transcription 4 (STAT4) & 0.19 & 0.12 & 0.09 & 0.06 \\
\hline lon transport & T5220। & chloride intracellular channel 2 (CLIC2) & 0.60 & 0.40 & 0.48 & 0.32 \\
\hline Metabolism & AA66882I & chitinase 3-like 2 (CHI3L2) & 0.42 & 0.45 & 0.61 & 0.15 \\
\hline Mitosis, regulation of CDK activity & AA608568 & cyclin A2 (CCNA2) & 0.36 & 0.42 & 0.44 & 2.90 \\
\hline Neurogenesis & AA425008 & cerebellin I precursor (CBLNI) & 1.09 & 0.37 & 0.20 & 0.21 \\
\hline Oncogenesis & W69960 & Wolf-Hirschhorn syndrome candidate I (WHSCI) & 0.12 & 0.10 & 0.05 & 0.10 \\
\hline Protein amino-acid phosphorylation & AA59884I & $\begin{array}{l}\text { natriuretic peptide receptor A/guanylate cyclase A } \\
\text { (atrionatriuretic peptide receptor A) (NPRI) }\end{array}$ & 0.46 & 0.34 & 0.74 & 0.41 \\
\hline Proteolysis and peptidolysis & H94487 & cathepsin E (CTSE) & 0.79 & 0.39 & 0.34 & 0.12 \\
\hline Regulation of cell cycle & $\mathrm{H} 73724$ & cyclin-dependent kinase 6 (CDK6) & 0.27 & 0.53 & 0.15 & 0.10 \\
\hline $\begin{array}{l}\text { Regulation of transcription, DNA } \\
\text { dependent }\end{array}$ & H82435 & myeloid/lymphoid or mixed-lineage leukaemia 3 (MLL3) & 0.29 & 0.46 & 0.39 & 0.56 \\
\hline $\begin{array}{l}\text { Regulation of transcription, DNA } \\
\text { dependent }\end{array}$ & AA480906 & protein kinase $\mathrm{C}$ binding protein I (PRKCBPI) & 0.40 & 0.23 & 1.10 & 0.48 \\
\hline Signal transduction & H93332 & apolipoprotein $\mathrm{B}$ (including $\mathrm{Ag}(\mathrm{x})$ antigen) (APOB) & 0.37 & 0.49 & 0.56 & 0.46 \\
\hline Skeketal development & W58032 & frizzled-related protein (FRZB) & 0.67 & 0.45 & 0.43 & 0.35 \\
\hline Steroid metabolism & N92404 & sulphotransferase, oestrogen-preferring (STE) & 1.00 & 0.28 & 0.18 & 0.30 \\
\hline Unclassified & AA454819 & mitogen-activated protein kinase 3 (MAPK3) & 0.21 & 0.29 & 0.07 & 0.11 \\
\hline Unclassified & AA450024 & T-cell lymphoma invasion and metastasis 2 (TIAM2) & 0.16 & 0.17 & 0.04 & 0.07 \\
\hline Unclassified & R89492 & $\begin{array}{l}\text { cytochrome P450, subfamily IIC (mephenytoin 4- } \\
\text { hydroxylase), polypeptide } 9 \text { (CYP2C9) }\end{array}$ & 0.49 & 0.50 & 0.55 & 0.29 \\
\hline Unclassified & AA487505 & immunoglobulin superfamily, member 4 (IGSF4) & 0.39 & 0.28 & 0.55 & 0.44 \\
\hline Unclassified & AA490903 & $\begin{array}{l}\text { pleckstrin homology, Sec7 and coiled/coil domains, binding } \\
\text { protein (PSCDBP) }\end{array}$ & 0.43 & 0.40 & 0.83 & 0.49 \\
\hline Unclassified & AA417616 & B-cell CLL/lymphoma 7A (BCL7A) & 0.35 & 0.22 & 0.13 & 0.09 \\
\hline
\end{tabular}

Representative functions of the genes as previously reported, accession number, gene name, and fold change of each radioresistant subline compared to their parent cell line are shown. Only the genes that showed more than two-fold change in at least three of the four radioresistant sublines are sorted by cDNA microarray data. 
A

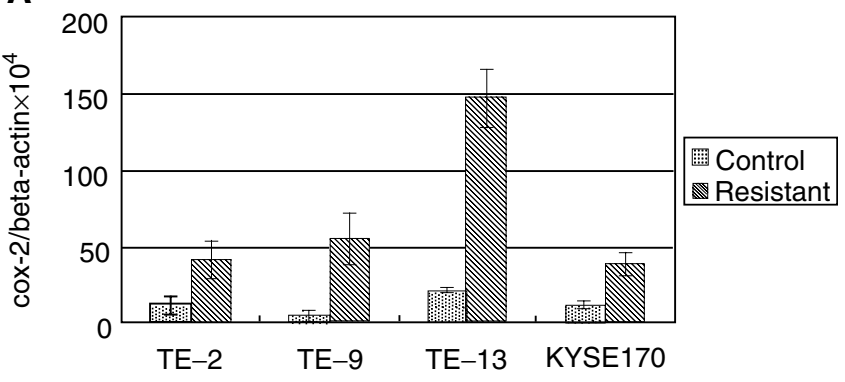

B

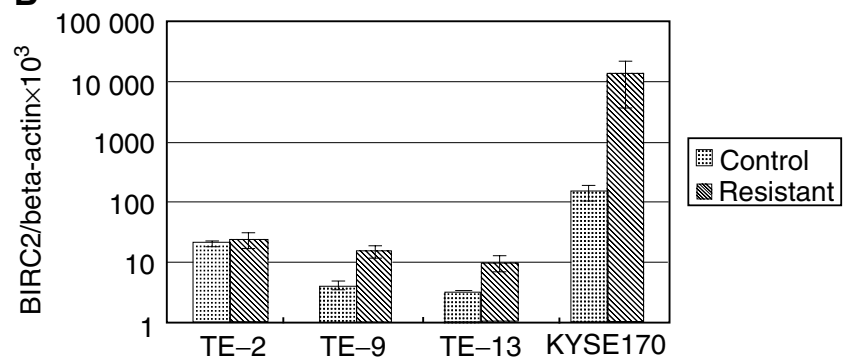

Figure I Quantitative RT-PCR analysis of the genes selected for cDNA microarray data validation. (A) Relative expression rate of COX-2 was normalised to beta-actin. (B) Relative expression rate of BIRC2 was normalised to beta-actin. Data represent mean \pm standard deviation $(n=3)$.

expression rates of COX-2 for group A were not significantly higher than those for group $\mathrm{B}$ (Figure $2 \mathrm{~A}, P=0.053$ ), the expression rates of BIRC2 for group A were significantly higher than those for group $\mathrm{B}$ (Figure $2 \mathrm{~B}, P=0.025$ ). These results suggest that genes, which are overexpressed in radioresistant sublines, may reflect clinical specimens of radioresistant cases.

\section{DISCUSSION}

Squamous cell oesophageal cancer shows intermediate-grade radiosensitivity, but even within the same histologic type, there is heterogeneous radiosensitivity. Radioresistance is an obstacle in cancer therapy and affects the curability of patients. Therefore, it is necessary to elucidate the radioresistance mechanisms to improve prognosis. Some investigators have tried to identify a set of genes related to radiosensitivity by comparing expression profiles of radiosensitive and radioresistant tumours obtained as clinical samples before treatment using a cDNA microarray (Hanna et al, 2001; Kitahara et al, 2002). However, it is very difficult to distinguish whether the radioresistance was inherent in the patient or the tissue itself or if it was acquired after cancer therapy. Thus, we thought that it is advantageous to compare cells of the same origin with and without radioresistance.

Radioresistant sublines were obtained by exposing the parent lines to repeated fractions of $2 \mathrm{~Gy}$, with 5-7 days recovery allowed between each fraction. This resulted in a statistically significant decrease in the radiosensitivity of the four exposed sublines as measured by clonogenic assay (Table 1). One explanation for the increased radioresistance might be an adaptive response to radiation, which has been observed in human lymphocytes (Olivieri et al, 1984). However, we observed that the radioresistant sublines maintained a radioresistant phenotype for at least 3 months after cessation of FIR. Russell et al (1995) explained that
A
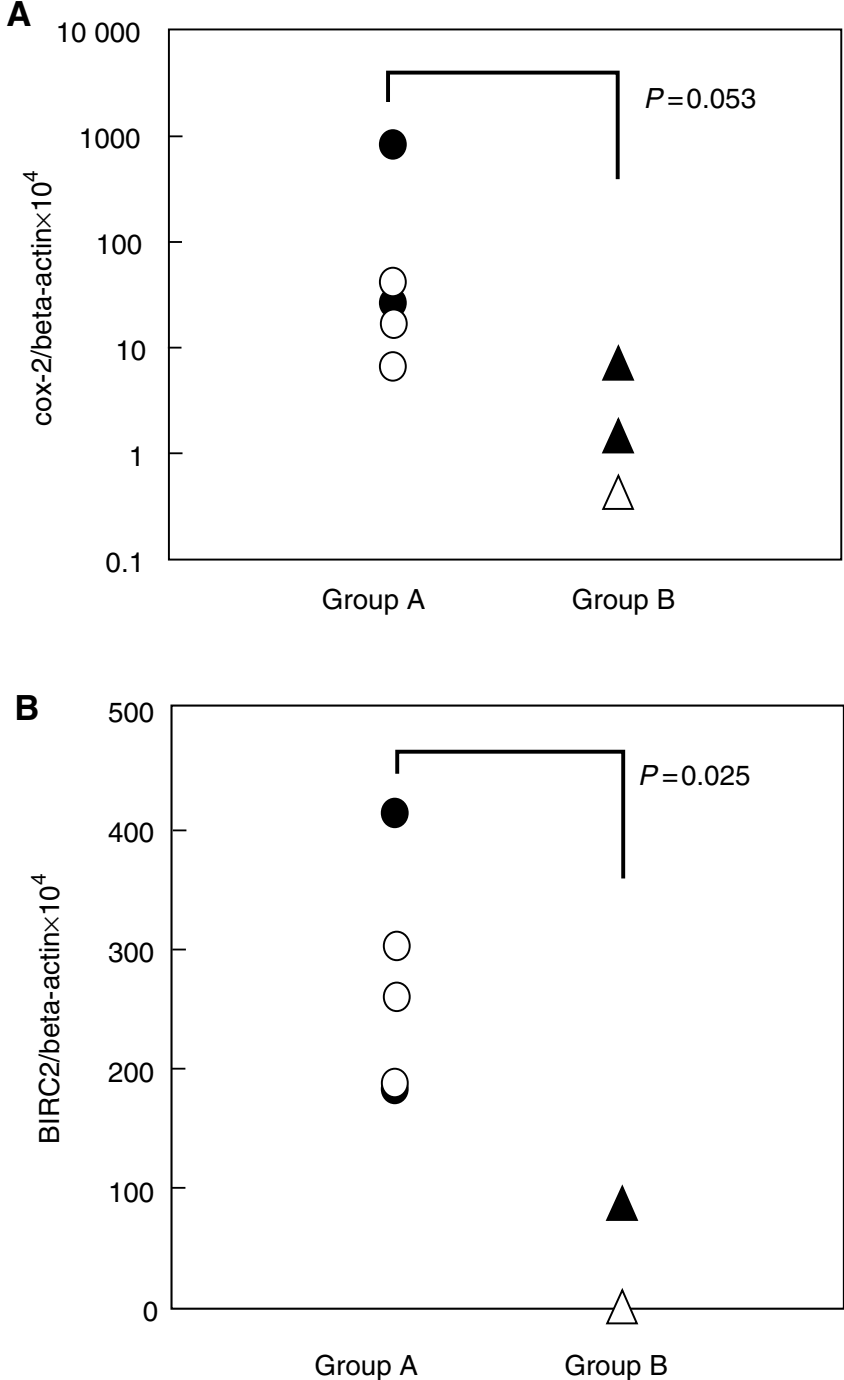

Figure 2 Effect of radiotherapy and expression rate of COX-2 $(\mathbf{A})$ and BIRC2 (B) in clinical specimens. Expression rates were normalised to betaactin. The grade of radiotherapy effect was determined based on the histopathological criteria of the Japanese Society for Esophageal Diseases. Grade $0(\mathbf{O})$, ineffective; Grade I $(\mathrm{O})$, slightly effective; Grade $2(\boldsymbol{\Delta})$, moderately effective; and Grade $3(\triangle)$, markedly effective. Group A included patients whose histological grade after radiotherapy was either 0 or I, and group B included patients whose grade was either 2 or 3 . The statistical analysis was performed using the Mann-Whitney U-test.

the selective pressure of repeated irradiation favours the emergence of radioresistant clones. Comparing the radioresistant sublines with their parent cell lines, we could truly examine genes associated with radioresistance.

A total of 19 upregulated (Table 3) and 28 downregulated (Table 4) genes were common to radioresistant sublines. With regard to radioresistance, malignant characteristics of cancer cells such as resistance to apoptosis, reduced intracellular adhesion, increased cell-matrix adhesion, and modified cell cycle are considered to be important features. Several of the 47 genes have been previously reported to be related to these features. The possible involvement of other genes listed in Tables 3 and 4 to radioresistance has not yet been reported. Other sequence tags (ESTs) can be expected to be involved in radioresistance, but the precise function of each gene remains unclear, so further study would be necessary to clarify this. 


\section{Genes related to apoptosis and cell cycle}

Prostaglandin-endoperoxide synthase (PTSG), also know as cyclooxygenase (COX), is the key enzyme in prostaglandin biosynthesis, and acts both as a dioxygenase and as a peroxidase. There are two isozymes of COX: a constitutive COX-1 and an inducible COX-2, which differ in their regulation of expression and tissue distribution. COX-2 is expressed in a limited number of cell types and regulated by specific stimulatory events, suggesting that it is responsible for the prostanoid biosynthesis involved in inflammation and mitogenesis. Recent studies have highlighted the relevance of COX-2 in human carcinogenesis (Eberhart et al, 1994; Ristimaki et al, 1997; Hida et al, 1998; Koga et al, 1999; Tucker et al, 1999). In oesophageal cancer, increased levels of COX-2 have also been reported (Hwang et al, 1998; Wilson et al, 1998; Katja et al, 1999; Shamma et al, 2000). Although the role of COX-2 in oesophageal cancer is not clear, it is possible that COX-2 is involved in the regulation of cell survival and maintenance of growth because COX-2 inhibitors are known to induce apoptosis and inhibit growth in oesophageal carcinoma cells (Katja et al, 1999). Furthermore, Pyo et al (2001) showed that selective COX-2 inhibitors enhanced the radiosensitivity of rat intestinal epithelial cells, which were stably transfected with COX-2 cDNA, and Nakata et al (2004) reported similar findings with human A431 epidermoid carcinoma. Our data suggest that COX-2 may play an important role in radioresistance induced by FIR, and COX-2 inhibitors may prevent tumour cells from acquiring radioresistance. Furthermore, in our preliminary clinical study, the expression rate of COX-2 tended to reflect the effect of radiotherapy (Figure $2 \mathrm{~A}, P=0.053$ ). Additional investigation will be necessary to confirm this hypothesis.

BIRC2, also known as cIAP1, is a gene that encodes an antiapoptotic molecule in the IAP family: oesophageal squamous cell carcinoma cell lines overexpressing this gene were resistant to apoptosis induced by chemotherapeutic reagents (Imoto et al, 2001). Furthermore, Imoto et al (2002) reported that the expression of cIAP1 was correlated with resistance of cervical cancers to radiotherapy. In our study, the expression rates of BIRC2 were significantly higher in patients whose histological grade after radiotherapy was either 0 or 1 than those patients whose histological grade was either 2 or 3 (Figure $2 \mathrm{~B}, P=0.025$ ). These data also suggest that we may predict the effect of radiotherapy using the expression rate of BIRC2.

Upregulation of ICEBERG, a caspase-1 inhibitor, and downregulation of caspase 6 (CASP6) are extremely intriguing. ICEBERG proteins are intracellular regulators of caspase-1 activation and could play a role in the regulation of $\mathrm{IL}-1 \beta$ secretion and NF- $\kappa \mathrm{B}$ activation during the proinflammatory cytokine response (Humke et al, 2000; Druilhe et al, 2001), NF$\kappa \mathrm{B}$ is a well-defined radiation-responsive transcription factor (Thanos and Maniatis, 1995). Furthermore, NF- $\kappa \mathrm{B}$ is associated with the cell cycle, and we found that cyclin A2 (CCNA2) was downregulated. However, genes such as $\mathrm{p} 53$, cyclin D1, and NF- $\kappa \mathrm{B}$ did not differ in our study, and the cell cycles of radioresistant sublines were similar to that of parent cell lines (Table 2). Another mechanism of cell cycle regulation may exist.

\section{REFERENCES}

Akimoto T, Mitsuhashi N, Saito Y, Ebara T, Niibe H (1998) Effect of radiation on the expression of E-cadherin and $\alpha$-catenin and invasive capacity in human lung cancer cell line in vitro. Int J Radiat Oncol Biol Phys 41: $1171-1176$

Biard DS, Martin M, Rhun YL, Duthu A, Leaix JL, May P (1994) Concomitant p53 gene mutation and increased radiosensitivity in rat lung embryo epithelial cells during neoplastic development. Cancer Res 54: $3361-3364$

\section{Genes related to growth and metabolism}

CD73, also termed $5^{\prime}$-nucleotidase, is a signalling pathway metabolite in the immune response of lymphocytes. This ectoenzyme catalyses the conversion of purine and pyrimidine ribo- and deoxyribonucleoside monophosphates (AMP, GMP, IMP) and leads to an elevation of the corresponding nucleosides (adenosine) in the extracellular space, perhaps modulating neuronal signalling and vascular perfusion, CD73 has also been called a cellular motility factor. There is an increasing amount of evidence for a modulatory role of PKC-mediated CD73 activity in ischaemia, regeneration and repair, glioma cell proliferation, and tissue invasion. Ludwig et al (1999) reported that CD73 expression was correlated with expression of protein kinase $\mathrm{C}$ (PKC) and epidermal growth factor receptor (EGFR). Protein kinase $\mathrm{C}$ is a known tumour metabolite in several proliferation-promoting pathways of EGF receptor signalling. Furthermore, Galmarini et al (2002) reported that CD73-positive acute myeloid leukaemia (AML) patients had worse disease-free survival and overall survival than negative patients, and suggested that CD73 expression might be a mechanism of resistance to cytarabine. To our knowledge, there have been no reports of an association between radioresistance and $\mathrm{CD} 73$.

\section{Genes related to cell adhesion and motility}

In our study, E-cadherin (CDH1), P-cadherin (CDH3), and protocadherin 9 (PCDH9) were downregulated in radioresistant sublines. However, Akimoto et al (1998) reported that E-cadherin expression was increased significantly in human squamous cell carcinoma after irradiation. This difference might be due to fractionated irradiation and acquisition of radioresistance. Some studies have shown that reduced E-cadherin expression was correlated with a high incidence of cancer metastasis and invasion (Doki et al, 1993; Kadowaki et al, 1994), and radiation enhanced the ability to form metastases (Sheldon and Fowler, 1976). Our results also suggest that the tumour cells that acquired radioresistance may have higher invasive ability and metastatic potential. Recently, an association between E-cadherin and COX-2 has been reported (Tsujii and Dubois, 1995), and Noda et al (2002) found that COX-2 inhibitors affect the transcription of E-cadherin.

Gene expression changes related to apoptosis, cell cycle, growth metabolism, and cell adhesion are likely to contribute to the complexity of radioresistance. It is unlikely that this phenomenon can be explained by altered expression of a single gene: whether this combination of gene expression changes leads to radioresistance of oesophageal cancers, however, is a matter to be investigated further. Identification of such genes could lead to new therapeutic targets.

\section{ACKNOWLEDGEMENTS}

We gratefully thank Dr Nishihira at Double Barred Cross Hospital for providing the TE-2, TE-5, TE-9, and TE-13 cell lines and Dr Shimada at Kyoto University for the KYSE170 and KYSE180 cell lines.
Brachman DG, Beckett M, Graves D, Haraf D, Vokes E, Weichselbaum RR (1993) p53 mutation does not correlate with radiosensitivity in 24 head and neck cancer cell lines. Cancer Res 53: 3667-3669

Coleman CN, Stevenson MA (1996) Biologic basis for radiation oncology. Oncology 10: 399-411

Dahlberg WK, Azzam EI, Yu Y, Little JB (1999) Response of human tumor cells of varying radiosensitivity and radiocurability to fractionated irradiation. Caner Res 59: 5365-5369 
DeRisi J, Penland L, Brown PO, Bittner ML, Meltzer PS, Ray M, Chen Y, Su YA, Trent JM (1996) Use of a cDNA microarray to analyse gene expression patterns in human cancer. Nat Genet 14: 457-460

Dewey WC, Ling CC, Meyn RE (1995) Radiation-induced apoptosis: relevance to radiotherapy. Int J Radiat Oncol Biol Phys 33: 781-796

Doki Y, Shiozaki H, Tahara H, Inoue M, Oka H, Iihara K, Kadowaki T, Takeuchi M, Mori T (1993) Correlation between E-cadherin expression and invasiveness in vitro in a human esophageal cancer cell line. Cancer Res 53: $3421-3426$

Druilhe A, Srinivasula SM, Razmara M, Ahmad M, Alnemri ES (2001) Regulation of IL-1 $\beta$ generation by Pseudo-ICE and ICEBERG: two dominant negative Caspase recruitment domain proteins. Cell Death Differ 8: $649-657$

Eberhart CE, Coffey RJ, Radhika A, Giardiello FM, Ferrenbach S, Dubois RN (1994) Up-regulation of cyclooxygenase 2 gene expression in human colorectal adenomas and adenocarcinomas. Gastroenterology 107: 1183 1188

Eifel PJ, Morris M, Wharton JT, Oswald MJ (1994) The influence of tumor size and morphology on the outcome of patients with FIGO stage IB squamous cell carcinoma of the uterine cervix. Int J Radiant Oncol Biol Phys 29: 9-16

Eisen MB, Spellman PT, Brown PO, Botstein D (1998) Cluster analysis and display of genome-wide expression patterns. Proc Natl Acad Sci USA 95: $14863-14868$

Galmarini CM, Thomas X, Calvo F, Rousselot P, Rabilloud M, Jeffari AE, Cros E, Dumontet C (2002) In vivo mechanisms of resistance to cytarabine in acute myeloid leukemia. Br J Haematol 117: 860-868

Gasparini G, Barbareschi M, Doglioni C, Palma PD, Mauri FA, Boracchi P, Bevilacqua P, Caffo O, Morelli L, Verderio P, Pezzella F, Harris AC (1995) Expression of bel-2 protein predicts efficacy of adjuvant treatments in operable node-positive breast cancer. Clin Cancer Res 1: 189-198

Golub TR, Slonim DK, Tamayo P, Huard C, Gaasenbeek M, Mesirov JP, Coller H, Loh ML, Downing JR, Caligiuri MA, Bloomfield CD, Lander ES (1999) Molecular classification of cancer: class discovery and class prediction by gene expression monitoring. Science 286: $531-537$

Hanna E, Shrieve DC, Ratanatharathorn V, Xia X, Breau R, Suen J, Li S (2001) A novel alternative approach for prediction of response of squamous cell carcinoma of head and neck. Cancer Res 61: 2376-2380

Hida T, Yatabe Y, Achiwa H, Muramatsu H, Kozaki K, Nakamura S, Ogawa M, Mitsudomi T, Sugiura T, Takahashi T (1998) Increased expression of cyclooxygenase 2 occurs frequently in human lung cancers, specifically in adenocarcinomas. Cancer Res 58: $3761-3764$

Hsiao M, Tse V, Carmel J, Costanzi E, Strauss B, Haas M, Silverberg GD (1997) Functional expression of human p21 (WAFI/CIPI) gene in rat glioma cells suppresses tumor growth in vivo and induces radiosensitivity. Biochem Biophys Res Commun 233: 329-335

Humke EW, Shriver SK, Starovasnik MA, Fairbrother WJ, Dixit VM (2000) ICEBERG: a novel inhibitor of interleukin-1 beta generation. Cell 103: $99-111$

Hwang D, Scollard D, Byrne J, Levine E (1998) Expression of cyclooxygenase- 1 and cyclooxygenase-2 in human breast cancer. $J$ Natl Cancer Inst 90: $455-460$

Imoto I, Yang ZQ, Pimkhaokam A, Tsuda H, Shimada Y, Imamura M, Ohki M, Inazawa J (2001) Identification of cIAP1 as a candidate target gene within an amplicon at 11q22 in esophageal squamous cell carcinomas. Cancer Res 61: 6629-6634

Imoto I, Tsuda H, Hirasawa A, Miura M, Sakamoto M, Hirohashi S, Inazawa J (2002) Expression of cIAP1, a target for 11q22 amplification, correlates with resistance of cervical cancers to radiotherapy. Cancer Res 62: $4860-4866$

Kadowaki T, Shiozaki H, Inoue M, Tamura S, Oka H, Doki Y, Iihara K, Matsui S, Iwazawa T, Nagafuchi A (1994) E-cadherin and a-catenin expression in human esophageal cancer. Cancer Res 54: $291-296$

Kaota K, Miki R, Bono H, Shimizu K, Okazaki Y, Hayashizaki Y (2001) Preprocessing implementation for microarray (PRIM): an efficient method for processing cDNA microarray data. Physiol Genomics 4: $183-188$

Kasid U, Pfeifer A, Weichselbaum RR, Dritschilo A, Mark GE (1987) The raf oncogene is associated with a radiation-resistant human laryngeal cancer. Science 237: 1039-1041

Katja CZ, Mario S, Artur-Aron W, Franz B, Helmut EG, Karsten S (1999) Cyclooxygenase-2 expression in human esophageal carcinoma. Cancer Res 59: $198-204$
Kitada S, Krajewski S, Miyashita T, Krajewska M, Reed JC (1996) Gammaradiation induces upregulation of Bax protein and apoptosis in radiosensitive cells in vivo. Oncogene 12: 187-192

Kitahara O, Katagiri T, Tsunoda T, Harima Y, Nakamura Y (2002) Classification of sensitivity or resistance of cervical cancers to ionizing radiation according to expression profiles of 62 genes selected by cDNA microarray analysis. Neoplasia 4: 295-303

Koga H, Sakisaka S, Ohishi M, Kawaguchi T, Taniguchi E, Sasatomi K, Harada M, Kusaba T, Tanaka M, Kimura R, Nakashima Y, Nakashima O, Kojiro M, Kurohiji T, Sata M (1999) Expression of cyclooxygenase-2 in hepatocellular carcinoma: relevance to tumor dedifferentiation. Hepatology 29: $688-696$

Ludwig HC, Rausch S, Schallock K, Markakis E (1999) Expression of CD73 (ecto-5'-nucleotidase) in 165 gliblastomas by immunohistochemistry and electron microscopic histochemistry. Anticancer Res 19: $1747-1752$

Mackey TJ, Borkowski A, Amin P, Jacobs SC, Kyprianou N (1998) bcl-2/bax ratio as a predictive marker for therapeutic response to radiotherapy in patients with prostate cancer. Urology 52: 1085-1090

Maity A, Kao GD, Muschel RJ, McKenna WG (1997) Potential molecular targets for manipulating the radiation response. Int Radiat Oncol Biol Phys 3: 639-653

Matsumura Y, Yamagishi N, Miyakoshi J, Imamura S, Takebe H (1997) Increase in radiation sensitivity of human Malignant melanoma cells by expression of wild-type p16 gene. Cancer Lett 115: 91 - 96

Meyn RE, Stephens LC, Milas L (1996) Programmed cell death and radioresistance. Cancer Metast Rev 15: 119-131

Nakata E, Manson KA, Hunter N, Husain A, Raju U, Liao Z, Ang KK, Milas L (2004) Potentiation of tumor response to radiation or chemoradiation by selective cyclooxygenase-2 enzyme inhibitors. Int J Radiat Oncol Biol Phys 58: $369-375$

Nishihira T, Hashimoto Y, Katayama M, Mori S, Kuroki T (1993) Molecular and cellular features of esophageal cancer cell lines. J Cancer Res Clin Oncol 119: 441 - 449

Noda M, Tatsumi Y, Tomizawa M, Takama T, Mitsufuji S, Sugihara H, Kashima K, Hattori T (2002) Effects of etodolac, a selective cyclooxygenase-2 inhibitor, on the expression of E-cadherin-catenin complexes in gastrointestinal cell lines. J Gastroenterol 37: 896-904

Olivieri G, Bodycote J, Wolff S (1984) Adaptive response of human lymphocytes to low concentrations of radioactive thymidine. Science 223: $594-597$

Pearce AG, Segura TM, Rintala AC, Rintala-Maki ND, Lee H (2001) The generation and characterization of a radioation-resistant model system to study radioresistance i n human breast cancer cells. Radiat Res 156: $739-750$

Pyo H, Choy H, Amorino GP, Kim JS, Cao Q, Hercules SK, DuBois RN (2001) A selective cyclooxygenase-2 inhibitor, NS-398, enhances the effect of radiation in vitro and in vivo preferentially on the cells that express cyclooxygenase-2. Clin Cancer Res 7: 2998-3005

Ristimaki A, Honkkanen N, Jankala H, Sipponen P, Harkonen M (1997) Expression of cyclooxygenase-2 in human gastric carcinoma. Cancer Res 57: $1276-1280$

Riva C, Lavielle JP, Reyt E, Brambilla E, Lunardi J, Brambilla C (1995) Differential c-myc, c-jun, c-raf and p53 expression in squamous cell carcinoma of the head and neck: implication in drug and radioresistance. Eur J Cancer B 31B: 384-391

Russell J, Wheldon TE, Stanton P (1995) A radioresistant variant derived from a human neuroblastoma cell line is less prone to radiation-induced apoptosis. Cancer Res 55: 4915-4921

Sakakura C, Hagiwara A, Nakanishi M, Shimomura K, Takagi T, Yasuoka R, Fujita Y, Abe T, Ichikawa Y, Takahashi S, Ishikawa T, Nishizuka I, Morita T, Shimada H, Okazaki Y, Hayashizaki Y, Yamagishi H (2002) Differential gene expression profiles of gastric cancer cell established from primary tumour and malignant ascites. Br J Cancer 87: 1153-1161 Sakakura C, Takemura M, Hagiwara A, Shimomura K, Miyagawa K, Nakashima S, Yoshikawa T, Takagi T, Kin S, Nakase Y, Fujiyama J, Hayasizaki Y, Okazaki Y, Yamagishi H (2004) Overexpression of dopa decarboxylase in peritoneal dissemination of gastric cancer and its potential as a novel marker for the detection of peritoneal micrometastases with real-time RT - PCR. Br J Cancer 90: 665-671

Shamma A, Yamamoto H, Doki Y, Okami J, Kondo M, Fujiwara Y, Yano M, Inoue M, Matsuura N, Shiozaki H, Monden M (2000) Up-regulation of cyclooxygenase-2 in squamous carcinogenesis of the esophagus. Clin Cancer Res 6: $1229-1238$ 
Sheldon PW, Fowler JF (1976) The effect of low-dose preoperative $\mathrm{X}$-irradiation of implanted mouse mammary carcinomas on local recurrence and metastasis. Br J Cancer 34: $401-407$

Shimada Y, Imamura M, Wagata T, Yamaguchi N, Tobe T (1992) Characterization of 21 newly established esophageal cancer cell lines. Cancer 69: 277-284

Sinclair WK, Morton RA (1966) X-ray sensitivity during the cell generation cycle of cultured Chinese hamster cells. Radiat Res 29: 450-474

Sklar MD (1988) The ras oncogenes increase the intrinsic resistance of NIH 3T3 cells to ionizing radiation. Science 239: 645-647

Thanos D, Maniatis T (1995) NF-kB: a lesson in family values. Cell 80: $529-532$

Tsujii M, Dubois RN (1995) Alterations in cellular adhesion and apoptosis in epithelial cells overexpressing prostaglandin endoperoxide synthase 2 . Cell 83: $493-501$
Tucker ON, Dannenberg AJ, Yang EK, Zhang F, Teng L, Daly JM, Soslow RA, Masferrer JL, Woerner BM, Koki AT, Fahey III TJ (1999) Cyclooxygenase-2 expression is up-regulated in human pancreatic cancer. Cancer Res 59: $987-990$

Weller M, Malipiero U, Aguzzi A, Reed JC, Fontana A (1995) Protooncogene bcl-2 gene transfer abrogates Fas/APO-1 antibody-mediated apoptosis of human malignant glioma cells and confers resistance to chemotherapeutic drugs and therapeutic irradiation. J Clin Invest 95: $2633-2643$

Wilson KT, Fu S, Ramanujam KS, Meltzer SJ (1998) Increased expression of inducible nitric oxide synthase and cycloooxygenase-2 in Barrett's esophagus and associated adenocarcinomas. Cancer Res 58: $2929-2934$ 